\title{
Męskości hybrydowe, czyli wilk w owczej skórze. Definiowanie konceptu
}

PRZEGLĄD KRYTYCZNY

2021 / 3(2): 35-50

ISSN: $2657-8964$

DOI: 10.14746/pk.2021.3.2.2

\section{Urszula Kluczyńska ${ }^{\mathbf{1}}$}

${ }^{1}$ Collegium Da Vinci w Poznaniu, Wydział Nauk Społecznych, ul. gen. Tadeusza Kutrzeby 10, 61-719 Poznań. ORCID: 0000-00025139-6813,Email: ulaklu@wp.pl

STRESZCZENIE: Krytyczne studia nad mężczyznami i męskościami oferują coraz większą pulę terminów i kategorii opisujących męskości oraz zależności genderowe. Najbardziej zananą teorią, która zmonopolizowała badania w obrębie studiów, jest teoria męskości hegemonicznej R.W. Connell. Teoria ta została poddana krytyce, która przyczyniła się do wyłonienia kolejnych propozycji opisu męskości. Jedną z takich propozycji są męskości hybrydowe. Celem tekstu jest poszerzenie dostępnych w języku polskim opisów i krytyki koncepcji teoretycznych w obrębie krytycznych studiów nad mężczyznami i męskościami. Autorka skupiła się na przybliżeniu koncepcji męskości hybrydowych. W ramach opisu kategorii męskości hybrydowych autorka wskazała na sposoby definiowania konceptu, opisała konsekwencje hybrydyzacji oraz odniosła się do badań, które wykorzystały tę kategorię analityczną lub których wnioski odnosiły się do męskości hybrydowych. Koncept męskości hybrydowych został również ukazany na tle wybranych kategorii męskości i poddany dyskusji.

SŁOWA KLUCZOWE: socjologia męskości, męskości hybrydowe, męskość hegemoniczna, krytyczne studia nad męskościami i mężczyznami, KSMM

\section{WSTĘP}

$\mathrm{R}$ ozwój krytycznych studiów nad mężczyznami i męskościami (KSMM) jest związany z wypracowywaniem nowych teorii, terminów i kategorii opisujących męskości. Mimo, że w Polsce prowadzone są badania nad męskościami i mężczyznami, to zwykle w ramach analiz wykorzystywane są kategorie wypracowane przez zachodnie badaczki i badaczy (por. Kluczyńska 2018). Najbardziej znaną, a jednocześnie szeroko krytykowaną (Beasley 2008a, Beasley 2008b; Demetriou 2001; Donaldson 1993; Hearn 1996; Hearn 2004; Hearn 2009; Howson 2005; Hawson 2008; Wetherell, Edley 1999; 
Whitehead 1999; Whitehead 2002) teorią jest teoria męskości hegemonicznej (hegemonic masculinity) (Connell 1995), która w Polsce nadal stanowi najczęściej wykorzystywaną perspektywę analityczną. Jest to podejście ukazujące męskości w porządku hierarchicznym, gdzie wytwarzane męskości odnoszą się do pewnego normatywnego wzorca, który można opisać jako: „konfigurację praktyk genderowych, które uosabiają współcześnie akceptowaną odpowiedź na problem legitymizacji patriarchatu, który gwarantuje (lub jest traktowany jako gwarancja) dominującą pozycję mężczyzn i podporządkowanie kobiet" (Connell 1995: 77). Jest to teoria, która - choć pod wpływem krytyki została ponownie przemyślana, a jej założenia zostały zrewidowane (Connell, Messerschmitt 2005) - nadal jest krytykowana jako strukturalizująca i wykorzystująca postmodernistyczne terminy przy modernistycznym opisie (Berggren 2014). Elementem krytyki teorii męskości hegemonicznej była również monopolizacja sposobu myślenia o męskościach i braku różnorodności pod względem teorii umożliwiających analizy w obrębie studiów.

Krytyka i dalsze badania przyczyniły się do wyłonienia kolejnych - poza dominującą w studiach teorią męskości hegemonicznej i związanych z nią męskościami współuczestniczącymi (complicit masculinities), marginalizowanymi (marginalized masculinities) i podporządkowanymi (subordinate masculinities) - propozycjami i teoriami. W ramach krytycznych studiów nad mężczyznami i męskościami wskazuje się między innymi na męskości toksyczne (toxic masculinities) (Kimmel 1995), czy zaproponowaną przez Erica Andersona (2009) męskość inkluzywną (inclusive masculinity), a także męskości hybrydowe (hybrid masculinities) (Bridges, Pascoe 2014), męskości opiekuńcze (caring masculinities) (Elliott 2015; Kluczyńska 2017a), czy męskość obronną (protective masculinity) (Wojnicka 2021). Są to charakterystyki uwzględniające zależności i relacje genderowe, zarówno w obrębie męskości, jak i męskości i kobiecości, które przyczyniają się do wyłonienia pewnych opisów męskości (Waling 2018). Dogłębna analiza zaproponowanych terminów - która nie jest możliwa do zaprezentowania w tym artykule - pokazuje, że szereg tych kategorii męskości często nakłada się na siebie, a czasami trudno ukazać rozdzielność lub relacje między owymi charakterystykami.

Przykładem analiz mających na celu opisać zależności i relacje między teoriami męskości jest sugestia Karli Elliott (2020a, 2020b), która proponuje by pisać o otwartych (open) i zamkniętych (closed) męskościach. Elliott lokuje koncept otwartych i zamkniętych męskości w ramach pojęciowych marginesu-centrum w relacji do mężczyzn i męskości. Łączy otwarte męskości z marginesem, a zamknięte męskości z centrum. Mężczyźni mogą być pozycjonowani w relacji do przestrzeni centrum lub marginesu między innymi w zależności od dostępu lub braku dostępu do władzy i przywilejów.

Powyższy, zaproponowany przez Elliott (2020a, 2020b), przykład porządkowania i ukazywania dynamiki zmian w obrębie męskości wymaga znajomości teorii i terminologii wspomnianych wcześniej męskości. Także przyjrzenie się relacjom w obrębie męskości jest możliwe tylko przy bliższym poznaniu charakterystyk wspomnianych wyżej męskości. Ponieważ literatura przedmiotu dostępna w języku polskim w niewielkim stopniu opisuje i dyskutuje wspomniane męskości, w ramach poniższych analiz podjęta została próba opisu męskości hybrydowej i uchwycenia jej specyfiki w kontekście wybranych opisów męskości. 


\section{KRYTYKA MĘSKOŚCI HEGEMONICZNEJ I JEJ HYBRYDYZACJA}

Krytyka teorii męskości hegemonicznej przyczyniła się do rozwoju sposobu myślenia o mężczyznach i męskościach, stała się też przyczynkiem do opisu męskości w kategoriach hybrydy. Dlatego w odniesieniu do analiz męskości hybrydowych odniosę się do teorii męskości hegemonicznej, by ukazać jak krytycy tej teorii postrzegali zmienność męskości hegemonicznej, podkreślając jej hybrydyzację. W kontekście definiowania męskości hybrydowych krytyka ta skupia się na kwestiach hegemoni zewnętrznej i wewnętrznej, aspektów istotnych w opisie specyfiki męskości hybrydowych.

Demetrakis Z. Demetriou (2001) krytykując koncepcję R.W. Connell (1995) podkreślił, że badaczka nie uwzględniła wpływu męskości podporządkowanych i marginalizowanych na kształt męskości hegemonicznej. Zdaniem Demetriou (2001: 337) męskość hegemoniczna nie jest wyłącznie białą lub heteroseksualną konfiguracją praktyk, ale to hybrydowy blok (hybrid masculine bloc), który jednoczy różnorodne męskości w celu zagwarantowania reprodukcji patriarchatu. Ponieważ Dematriou (2001: 341) analizuje męskość hegemoniczną w relacji do kobiet i w relacji do męskości podporządkowanych, a zatem wydziela hegemonię zewnętrzną i wewnętrzną. Męskość hegemoniczną, rozumianą jako zewnętrzną hegemonię, łączy z zinstytucjonalizowaną dominacją mężczyzn nad kobietami, z kolei wewnętrzną hegemonię łączy z hegemonią mężczyzn nad innymi mężczyznami. Jak zaznacza R.W. Connell (1995: 76-81) model męskości hegemonicznej jest nieosiągalny dla większości mężczyzn i stanowi raczej pewien „ideał kulturowy”, który reprodukuje patriarchat. Mężczyźni, którzy nie realizują wzorca męskości hegemonicznej, ale podtrzymują go i realizują patriarchalną dywidendę są określani jako współuczestniczący (complicit). Gdy zmieniają się warunki umożliwiające reprodukcję patriarchatu dochodzi do zmian w obrębie męskości hegemonicznej i dlatego Demetriou podkreśla, że męskość hegemoniczna jest strategią podporządkowania kobiet, a także pozwala na podporządkowanie mężczyzn (Demetriou 2001: 343). Pewne męskości zalicza się do podporządkowanych nie dlatego, że brakuje im jakiejś jakości lub że są w jakiś sposób naturalny podporządkowane. Są one podporządkowane, ponieważ konfiguracja praktyk, które reprezentują, których są ucieleśnieniem, są sprzeczne z aktualnie akceptowaną strategią podporządkowania kobiet. Jako przykład Demetriou (2001: 344) podaje gejów i wskazuje, że są oni podporządkowani, gdyż obiekt ich seksualnego pożądania podkopuje instytucję heteroseksualności, która ma kluczowe znaczenie dla reprodukcji patriarchatu.

By ukazać zdolność włączania elementów męskości podporządkowanych i marginalizowanych w męskość hegemoniczną, Demetriou (2001) zastosował termin „dialektyczny pragmatyzm”. Autor twierdzi, że to, co czyni męskość hegemoniczną tak silną, to właśnie umiejętność adaptacji. Proponuje on rozumieć męskość hegemoniczną jako blok zdolny do zawłaszczania tego, co jest użyteczne i konstruktywne dla projektu dominacji w danym momencie historycznym (Demetriou 2001: 345). Demetriou (2001: 347-348) próbuje dekonstruować binaryzm między niehegemonicznymi męskościami a hegemoniczną męskością i proponuje termin hybrydowego bloku, który łączy różnorodne praktyki w celu stworzenia najlepszej możliwej strategii dla reprodukowania patriarchatu. Konfiguracja praktyk, która gwarantuje reprodukcję patriarchatu nie 
musi być związana wyłącznie z białą, heteroseksualną męskością. Wewnętrzne zróżnicowanie i hybrydyczna natura czyni blok męskości hegemonicznej dynamicznym i elastycznym, adoptującym się do zmian. Kształtuje się on raczej przez „negocjacje, a nie negację" (Bhabha 1998: 11). Hybrydyzacja jest zatem strategią reprodukcji patriarchatu.

Wraz z krytyką teorii męskości hegemonicznej przeprowadzono badania dotyczące różnych grup mężczyzn, które opisywały hybrydyzację męskości. By zobrazować mechanizmy i konsekwencje hybrydyzacji odwołam się do poszczególnych wniosków z wybranych badań w dalszej części tekstu. Pozwolą one szczegółowo zobrazować dany mechanizm i związane z nim konsekwencje. Tutaj podam kilka przykładów badań, które pozwolą przenieść teoretyczne analizy zaprezentowane powyżej na konkretne przykłady i pokazać bardzo ogólnie założenia hybrydyzacji męskości.

Przykładem badań, które pozwolą lepiej zrozumieć specyfikę hybrydyzacji męskości, są między innymi analizy Briana Donovana (1998). Autor badał ruch Promise Keepers i na tym przykładzie przybliżył sposób konstruowania męskości hybrydowej. Badacz ukazał, że męskość hybrydowa stanowi kombinację zarówno wrażliwości jak i siły mężczyzny, przez co produkowana jest nowa forma władzy, która wspiera męski autorytet. Zdaniem Schindlera, na którego powołuje się Sarvan (1998), członkowie ruchu Promise Keepers starają się odzyskać tradycyjne role genderowe za pomocą dyskursu inkluzyjności, współczucia i braterstwa.

Demetriou (2001: 349-355) opisuje jako jeden z przykładów hybrydyzacji włączenie elementów kultury gejowskiej do męskości heteroseksualnej. W swych analizach pokazuje jak włączenie elementów kultury gejowskiej przyczynia się do powstania męskości hybrydowej umożliwiającej dominację nad kobietami. Wskazuje, że męskość hegemoniczna umożliwiająca reprodukcję patriarchatu nie jest konstruowana w całkowitej opozycji do męskości gejowskich. Wiele elementów męskości gejowskich wchodzi w skład hybrydowego bloku, którego różnorodność przyczynia się do niewidoczności patriarchalnej dywidendy i legitymizacji męskiej dominacji. Ta hybrydyzacja przyczynia się do złudnego przekonania, że praktyki genderowe stają się mniej opresyjne i bardziej egalitarne (Demetriou 2001: 354-355).

Włączenie dbałości o wygląd, ubiór czyni dominującą formę męskości łagodniejszą, delikatniejszą i na poziomie symbolicznym nie będącą w opozycji do współczesnych kobiecości. Jednak według Donovana (1998: 837) jest to złudzenie, gdyż delikatniejsze, „miękkie” formy męskości nie wpływają na emancypację kobiet, ale raczej maskują uzurpację kobiecych praw, a zatem hybrydyzacja jest rodzajem kamuflażu, maskarady umożliwiającej utrzymanie reprodukcji patriarchatu (Demetriou 2001: 355).

Podobne wnioski na temat wyłaniającej się męskości hybrydowej wysunął Michael Messner opisując Arnolda Schwarzenegera, który uzyskał fotel gubernatora Kalifornii (Messner 2007). Badania te ukazują przykład kombinacji siły i delikatności w sposób, który przyczynia się raczej do ukrycia niż podważania systemu władzy i nierówności (Bridges, Pascoe 2014). 


\section{MĘSKOŚCI HYBRYDOWE WEDŁUG TRISTANA BRIDGES’A I C.J. PASCOE}

Powyżej wskazałam, jak krytyka teorii męskości hegemonicznej przyczyniła się do dostrzeżenia hybrydyzacji i na kilku przykładach badań odniosłam się do badań ukazujących całościowy obraz specyfiki męskości hybrydowej, by dać wyobrażenie kierunku i rodzaju zmian. Męskości hybrydowe są bowiem zmianą męskości. Ta zmiana dotyczy kwestii hierarchii oraz podporządkowania i jest związana z kilkoma konsekwencjami. W dalszej części tekstu mechanizmy oraz konsekwencje hybrydyzacji zostaną przybliżone i zobrazowane przykładami badań.

Według Tristana Bridges i C.J. Pascoe męskości hybrydowe odnoszą się do selektywnej inkorporacji zachowań i elementów tożsamości łączonej z męskościami marginalizowanymi oraz podporządkowanymi i kobiecościami (Bridges \& Pascoe 2014: 246). „Po pierwsze, praktyki męskości hybrydowej kreują dyskursywny dystans pomiędzy młodymi, białymi, heteroseksualnymi mężczyznami i męskością hegemoniczną, umiejscawiając ich poza istniejącym systemem przywilejów i nierówności. Druga konsekwencja, dotyczy bazowania na założeniu, że męskości hybrydowe dostępne dla młodych, białych, heteroseksualnych mają mniejsze znaczenie niż męskości różnych marginalizowanych i podporządkowanych „Innych”, których tożsamości są przynajmniej częściowo wytwarzane przez zbiorowe zmagania o prawa i uznanie. Po trzecie, męskości hybrydowe wzmacniają symboliczne i społeczne granice pomiędzy grupami (seksualnymi, rasowymi, genderowymi), nadal głęboko zakorzenione, i często ukrywają nierówności, lecz dzieje się to nowymi sposobami” (Bridges, Pascoe 2014: 250).

Tristan Bridges i C.J. Pascoe (2014: 250-255) wskazują na trzy konsekwencje zwiazane z sposobem konstruowania męskości hybrydowych: dyskursywne dystanowanie (discursive distancing), strategiczne zapożyczanie (strategic borrowing) i wzmacnianie granic (fortifying boundaries). Opisują one proces, w którym znaczenie i praktyki męskości hegemonicznej podlegają zmianom na przestrzeni czasu w sposób podtrzymujący reżimy genderowe, dominację mężczyzn nad kobietami i dominację pewnych grup mężczyzn nad innymi mężczyznami (Bridges, Pascoe 2018: 261), a zatem dominację zewnętrzną i wewnętrzną.

Poniżej każda ze wspomnianych konsekwencji zostanie opisana i zobrazowana przykładami wybranych badań. Autorki i autorzy badań nie zawsze stosowali termin męskości hybrydowe, nie zawsze korzystali z tego terminu w tytule prac lub opisie badań. Opisywali jednak to zjawisko i związane z nim mechanizmy. By lepiej ukazać złożoność zjawiska w ramach charakterystyki kolejnych konsekwencji, będę odnosiła się czasami do tych samych badań, choć skupię się na innych ich aspektach.

\section{DYSKURSYWNE DYSTANSOWANIE}

Dyskursywne dystansowanie polega na stworzeniu przekonania, że męskość hybrydowa dystansuje się wobec męskości hegemonicznej, podczas gdy tak na prawdę wspiera ją.

Jednym z przykładów trafnie opisującym dyskursywne dystansowanie jest „bromance”. Bromance to bliska, emocjonalna, intymna, nie seksualna, choć uwzgledniająca intymny dotyk, relacja między mężczyznami. W słowie „bromance” jest romans, 
a zatem intymna więź, ale jest ona usytuowana miedzy osobami, które są kumplami. „Bro” symbolicznie podkreśla bowiem heteroseksualność relacji i dystansuje wobec erotycznej relacji mężczyzny z mężczyzną mimo, że w tej relacji możliwy jest intymny dotyk między mężczyznami. Relacja ta wydaje się redukować dystans między męskością hegemoniczną a intymnością i podważać istotę homofobii w kształtowaniu współczesnych męskości (Bridges, Pascoe 2018: 261).

Z kolei Bridges (2010) i Master (2010) podają przykłady praktyk mężczyzn, które mają pokazać wsparcie kobiet i umożliwiać dystansowanie się wobec seksizmu i dominacji nad kobietami, czyli elementów męskości hegemonicznej. Master i Brigdes nawiązują do dwóch kampanii sprzeciwiających się przemocy wobec kobiet “My Strength is Not for Hurting” oraz "Walk a Mile in Her Shoes". W efekcie dochodzi do hybrydyzacji męskości, lecz nie jest podważana nierówność, jest ona wręcz wzmacniana. W ramach kampanii "My Strength is Not for Hurting” (Master 2010), gwałciciele definiowani są jako nieautentyczni i słabi, podczas gdy mężczyźni, którzy nie gwałcą są autentyczni i silni. Tym sposobem siła, władza staje się prawdziwą męskością, a słabość jest utożsamiana z niemęskością lub kobiecością. Kampania ta przyczynia się zatem do wytwarzania dystansu pomiędzy „dobrymi” mężczyznami, którzy sprzeciwiają się przemocy genderowej oraz „złymi” hegemonicznymi męskościami, które wspierają tę przemoc. Mężczyźni, którzy gwałcą są mężczyznami patologicznymi, a zatem są marginalizowani, podczas gdy mężczyźni, którzy nie gwałcą są prezentowani jako uosabiający męskość hegemoniczną. Z kolei w kampania „Walk a Mile in Her Shoes” polega na tym, że mężczyźni ubierają buty na wysokich obcasach i idą w marszu przez milę protestując przeciwko przemocy wobec kobiet, przez co chcą pokazać solidarność z nimi. Te działania dystansują wobec męskości hegemonicznej. Bridges (2010) zaznacza, że żarty uczestników marszu dotyczące noszenia butów na wysokich obcasach i pożądaniu tej samej płci tak naprawdę są opowiedzeniem się po stronie męskości hegemonicznej, mimo, że wydają się jej sprzeciwiać.

Kristen Barber (2008), analizując salony piękności, opisała uczestnictwo mężczyzn w „kobiecych” aktywnościach jak np. pedicure i manicure. Udział w takich zabiegach ma dystansować wobec męskości dominującej. Jednak mężczyźni korzystający z usług upiększających ciała unikali feminizacji dzięki statusowi klasy uprzywilejowanej i określeniu owych usług upiększających ciało jako elementu, a nawet wymogu, wyglądu osób przynależących do klasy profesjonalistów. Kreowali się na postępowych w odniesieniu do kwestii genderowych i seksualnych, gdyż bez obaw uczestniczyli w „kobiecych” zabiegach.

Z kolei badania mężczyzn w pielęgniarstwie (Kluczyńska 2017a, 2017b) pokazały, że kategoria męskości hybrydowych może być użyteczna do opisu grupy mężczyzn, którzy zdają się realizować profesję jednoznacznie zbliżającą do kobiecości (Kluczyńska 2021). W ramach badań (Kluczyńska 2017a, 2017b) wyróżniono różne sposoby definiowania męskości i opieki. Kategoria męskości hybrydowych okazała się użyteczna w opisie pielęgniarzy, którzy deklarowali przekonanie o realizacji męskości hegemonicznej, choć w rzeczywistości realizowali raczej męskość współuczestniczącą (wykorzystując kategorie Connell). Grupę pielęgniarzy przekonanych o realizacji lub zbliżaniu się do wzorca męskości hegemonicznej charakteryzowało kilka cech. Byli to 
sprawni, biali, heteroseksualni mężczyźni o wysokich dochodach. Mimo, iż pracowali w zawodzie powszechnie uznawanym jako nisko dochodowy ich zarobki były wysokie, awansowali, pracowali w specjalistycznych pracowniach, mieli poczucie sprawstwa, nie obawiali się podejmowania ryzyka. Opiekę - ujmowaną raczej jako specjalistyczne zadania - definiowali jako element pracy, ale nie sfery prywatnej (Kluczyńska 2017a: 175). Z założenia, mężczyzn podejmujących się pracy opiekuńczej postrzega się jako mężczyzn realizujących męskość opiekuńczą, gdyż męskość hegemoniczna jest definiowana jako niepodejmująca opieki i cedująca działania opiekuńcze na męskości leżące niżej w hierarchii męskości oraz na kobiecości. Podjęcie praktyki kobiecej, czyli zawodu opiekuńczego dystansuje wobec męskości hegemonicznej. Ten dystans może być jednak pozorny, ponieważ istotne znaczenie ma sposób definiowania opieki przez mężczyzn pielęgniarzy. Realizacja zawodu pielęgniarskiego wydaje się redukować dystans między męskością hegemoniczną a opieką, i ukazywać opiekę jako element kształtowania współczesnych męskości. Tym sposobem zawód opiekuńczy redefiniuje opiekę, a tym samym umożliwia włączenie jej jako atrybutu męskości dominującej (Kluczyńska 2021).

Z kolei Arcimowicz (2020), analizując wybranych bohaterów neoseriali, opisuje postacie, wobec których stosuje określenie męskości hybrydowych, a których charakteryzuje łączenie elementów męskości hegemonicznych i niehegemonicznych (Arcimowicz 2020: 232). Analizowane postacie przechodzą pewną przeminę i podczas gdy początkowo postrzegane są przez pryzmat cech męskości niehegemonicznych, ewoluują ku męskości hegemonicznej. Tę zmianę można interpretować jako skuteczne włączenie elementów męskości podporządkowanych i redefinicję. Przykładem dystansowania wobec męskości hegemonicznej jest deklarowanie przez bohaterów ze świata przestępczego niechęci wobec przemocy. Autor badań zaznacza, że choć dochodzi do dystansowania wobec męskości hegemonicznej, to jednak te zabiegi nie służą dekonstrukcji dominacji, ale maskują patriarchalną władzę (Arcimowicz 2022).

Jak podsumowują Bridges i Pascoe (2014: 252), męskość hybrydowa wytwarza przestrzeń, dystans między mężczyzną a męskością hegemoniczną, podczas gdy tak naprawdę powiela relacje władzy i nierówności. Dzieje się tak nie tylko na poziomie lokalnym, ale też globalnym.

\section{STRATEGICZNE ZAPOŻYCZANIE}

Męskości hybrydowe realizowane są przez mężczyzn z grup uprzywilejowanych. Zapożyczają oni symbole lub praktyki łączone z podporządkowanymi „Innymi”, przez co „zbliżają się” do członków grupy podporządkowanej, choć nie są ich częścią (Bridges, Pascoe 2018: 263-264).

Strategiczne zapożyczanie wykorzystywane jest na przykład w kulturze hipsterskiej, która wykorzystuje elementy klasy robotniczej. Inny przykład to włączenie elementów kultury gejowskiej wśród mężczyzn identyfikujących się jako heteroseksualni, czyli metroseksualność (Bridges, Pascoe 2018:263-264). Przykładem strategicznego zapożyczania jest odwoływanie się mężczyzn do problemu seksizmu i określania siebie jako jego ofiary (Messner 1993: 77). Innym przykładem może być określanie kobiet 
jako dominujących lub dążących do dominacji i stosowanie do opisu tej sytuacji określeń takich jak: mizoandria, gynocentryzm czy matriarchat (Kimmel 2017: 99-134). Mężczyźni są tym sposobem określani jako ofiary poprzez przesadne podkreślanie społecznych kosztów i norm męskości (Haverda 2019:15).

Michael Messner ukazał hybrydyzację męskości na przykładzie konstruktu nowego mężczyzny (new man) i nowego ojcostwa (new fathering), które w opinii badacza stanowią raczej zmianę stylu niż istoty (Messner 1993: 77). Nowe ojcostwo może być postrzegane jako postępowe i prorównościowe. Spędzanie czasu z dzieckiem, bliższa emocjonalna relacja z dzieckiem - jako podstawy nowego ojcostwa - nie zmieniają jednak relacji nierówności genderowych w rodzinie. Messener wskazuje, że zamiast relacji genderowej możemy tu mówić raczej o stylu rodzicielstwa realizowanego przez mężczyzn.

Steven Arxer (2011) badając konwersacje mężczyzn w barach ukazał sposoby, w jakich mężczyźni konceptualizują i negocjują ideały męskości i wytwarzają hybrydową formę męskości hegemonicznej włączającej niehegemoniczne praktyki. Zachowanie mężczyzn było dalekie od rywalizacji, obojętności emocjonalnej, czy działań uprzedmiatawiających seksualnie kobiety. Badani mężczyźni dążyli do zachowywania się w sposób, który łączony jest z zachowaniem gejów, ale ich celem było „zaliczenie” kobiety.

Innym przykładem zapożyczenia, czyli przejmowania symboli i praktyk łączonych z męskościami podporządkowanymi i kobiecościami, jest realizacja opieki w pielęgniarstwie we wspomnianych wcześniej badaniach wśród pielęgniarzy (Kluczyńska 2017a, 2017b). Biali, heteroseksualni pielęgniarze zapożyczają opiekę, wchodzą w zawód, redefiniują swoją pozycję, wykorzystują swoje atrybuty (bycie białym, heteroseksualnym mężczyzną) i podkreślają swoją odmienność w stosunku do grup podporządkowanych (kobiet pielęgniarek, gejów pielęgniarzy), co wzmacnia system dominacji i hierarchiczny układ (Kluczyńska 2021). Dochodzi do zapożyczenia praktyki i jej redefinicji. Opieka z założenia definiowana jest jako niehegemoniczna. Ważne jest jednak to, że część pielęgniarzy redefiniuje opiekę, która staje się w ich narracjach odmienna, staje się opieką „po męsku”, czyli specjalistyczną, mniej emocjonalną, w skład której nie wchodzą zadania pielęgnacyjne „brudne”, te o najniższym statusie. Tak więc pielęgniarze podejmują się opieki, ale jest ona fachowa, mniej emocjonalna, bardziej techniczna. Opieka, czy raczej redefinicja opieki, może potwierdzać tu męskość (Kluczyńska 2021).

Z kolei Arcimowicz (2022), opisując bohaterów Domu z papieru, wskazuje na wykorzystanie strategii zapożyczania w sposobie konturowania męskości protagonistów. Ukazuje on, jak dochodzi do włączania gestów i mimiki oraz reakcji na stres, a także słabości cielesnej, w obraz męskości realizowanej przez bohaterów. Bohaterowie zapożyczają emocjonalność, wrażliwość i okazywanie uczuć, a zatem elementy męskości niehegemonicznej i włączają je w realizowany wzorzec męskości.

\section{WZMACNIANIE GRANIC}

Zdaniem Bridgesa i Pascoe (2014:254) przejęcie elementów lub praktyk męskości pod- 
porządkowanych przez młodych, białych, heteroseksualnych mężczyzn przyczynia się do zacierania granic między grupami. Męskości hybrydowe wzmacniają i ukrywają system nierówności na historycznie nowe sposoby, często podobnie do rasy, genderu, seksualności lub klasy. Pozorne zamazanie różnic, tak naprawdę przyczynia się do wzmocnienia granic między grupami mężczyzn.

Jane Ward (2015) - badając białych heteroseksualnych mężczyzn uprawiających seks z innym identyfikującym się jako heteroseksualny mężczyzna - ukazała specyfikę procesu umacniania granic. Ward wskazuje, że badani mężczyźni uprzedmiatawiali kobiety, odrzucali feminizację mężczyzn, a „nie-białych” mężczyzn postrzegali jako najbardziej erotycznych. Ward określa relację między badanymi mężczyznami jako „dude sex” (sex miedzy kolesiami). Takie określenie relacji podważa, ale jednocześnie wzmacnia system władzy i nierówności. Ward ukazuje, jak angażowanie się mężczyzny w relacje seksualną z innym mężczyzną może udowadniać męskość dzięki przynależności do danej rasy oraz klasy społecznej, i określa ów proces jako „hetero-wyjątkowość” (hetero-exceptionalism). Analizy te pokazują, że biali mężczyźni uznający się za heteroseksualnych mogą uprawiać seks z innymi mężczyznami bez konsekwencji tożsamościowych.

Opisane wcześniej badania Stevena Arxer’a (2011) pokazały, jak inkorporacja zachowań niehegemonicznych pozwala uzyskać hegemoniczny cel, ale pozwala też wzmocnić granice. To zapożyczenie w istotny sposób wpływa na kwestię hierarchii męskości. Jeśli młody, heteroseksualny, biały mężczyzna zapożycza praktyki i elementy tożsamości od gejów czy czarnych mężczyzn w celu zwiększenia swojego męskiego kapitału, to wówczas jednocześnie owe zapożyczane elementy potwierdzają dewiacyjny charakter owych podporządkowanych grup. A zatem tym sposobem wzmacniają istniejący system władzy i dominacji, dochodzi do wzmocnienia granic (por. Bridges, Pascoe 2014:253).

Z kolei badania Kristen Barber (2008), która analizowała udział mężczyzn w zabiegach kosmetycznych, pokazały również, jak dochodzi do wzmocnienia granicy. Mężczyźni korzystający z usług upiększających salonów kosmetycznych dystansowali się wobec klasy robotniczej określanej jako mizoginistycznej i antyrównościowej. Dystansowanie związane jest z wykluczeniem z tej praktyki klasy robotniczej, której nie stać na usługi, a na które może sobie pozwolić grupa profesjonalistów.

W badaniach dotyczących udziału mężczyzn w pielęgniarstwie (Kluczyńska 2017a, 2017b, 2021) pokazano, jak biali, heteroseksualni pielęgniarze zapożyczają praktykę opieki, redefiniują jej znaczenie, korzystają z patriarchalnej dywidendy i odróżniają się od grup podporządkowanych, wzmacniając tym sposobem porządek genderowy i hierarchiczny system dominacji. Tym sposobem dochodzi do wzmocnienia granic, które tylko pozornie zostały podważone. Opisane wcześniej redefiniowanie opieki i podejmowanych zadań oraz wykorzystanie przywilejów w sfeminizowanej profesji pozwala się odróżnić, wzmocnić granicę między opiekuńczą kobiecością, męskościami opiekuńczymi i podporządkowanymi (przede wszystkim gejami). To „inni”, czyli podporządkowani, realizują tę opiekę o najniższym statusie. Tak dochodzi do wzmacniania granic. Choć na inny sposób, ale i tak podział na „my” i „oni” („Inni”) działa. Biali heteroseksualni mężczyźni mogą pracować jako pielęgniarze bez konsekwencji 
tożsamościowych, gdyż udział w opiece - jeśli uwzględnimy powyższy sposób rozumienia opieki - nie wpływa na sposób definiowania męskości (Kluczyńska 2021).

\section{MĘSKOŚCI HYBRYDOWE A MĘSKOŚCI DOMINUJĄCE I PODPORZĄDKOWANE}

By przyjrzeć się aspektowi hybrydyzacji męskości warto odnieść się do funkcjonujących kategorii męskości. Ponieważ pewnym dualizmem jest tu grupa męskości dominujących i podporządkowanych oraz przyglądanie się hybrydyzacji z perspektywy władzy lub jej braku, po krótce odniosę się do wybranych sposobów opisu męskości. Ponieważ męskość hegemoniczna i jej krytyka dostępne są również w polskiej literaturze przedmiotu (Kluczyńska 2017:14-22), do czego częściowo odniosłam się na początku tekstu, nie będę powtarzała tego opisu. Warto jednak przypomnieć, że konstrukt męskości hybrydowych bazuje na teorii męskości hegemonicznej, stąd odwołania doń są niezbędne.

Odnosząc się do męskości „dominujących” i pisząc o męskości hegemonicznej i hybrydyzacji nie można zapomnieć o męskościach określonych przez R.W Connell (1995) jako współuczestniczące. Są to męskości, które nie realizują męskości hegemonicznej, ale mają dostęp do władzy. Są one bardziej pasywnym wyrazem męskości i nie realizują w pełni męskości hegemonicznej. Uzyskują jednak profity w formie patriarchalnej dywidendy. Odnosząc się do męskości hybrydowych opisanych przez Bridges’a i Pascoe $(2014$; 2018) warto zaznaczyć, że dyskursywny dystans przyczynia się do konstruowania męskości współuczestniczących, czyli jak pisze Connell (Connell 2005: 7980) męskości korzystającej z nierówności miedzy kobietami i mężczyznami. Dostęp do władzy i dominacja męskości hegemonicznych jest oczywista. Pamiętać jednak warto, że - wykorzystując tu kategorie zaproponowane przez R.W. Connell, bo są one nadal istotnym narzędziem opisu - również męskości współuczestniczące zyskują dzięki hybrydyzacji. Co prawda „idącą na pewne ugody”, ale nadal korzystającą z przywilejów męskości. Zgodnie z teorią R.W Connell (1995) męskość hegemoniczna jest dostępna dla niewielu, jednak to nosiciele męskości współuczestniczącej dominują w analizowanych badanych.

Korzyści z hybrydyzacji męskości w kontekście męskości hegemonicznych i współuczestniczących są niewątpliwe. Hybrydyzacja jest mechanizmem pozwalającym reprodukować patriarchat (Demetriou 2001). Jest zatem na usługach męskości dominujących. Wskazuje na to w zasadzie cały powyższy tekst oraz analizy Bridges’a i Pascoe (2014; 2018). Dominacja i podporządkowanie, hierarchia zewnętrzna i wewnętrzna to oś konstruowania męskości hybrydowych. Jakie jest zatem miejsce męskości podporządkowanych, a także męskości marginalizowanych w kontekście hybrydyzacji?

Męskości marginalizowane charakteryzuje brak pewnej jakości męskości hegemonicznej, na przykład siły fizycznej i tu przykładem będą mężczyźni z niepełnosprawnościami (Connell 1995). Męskości marginalizowane są trywializowane lub dyskryminowane ze względu na relacje inne niż genderowe, czyli na przykład wiek, przynależność etniczna czy klasa. Z kolei męskości podporządkowane nie tyle charakteryzuje brak jakiejś cechy, jak w przypadku męskości marginalizowanych, ale ukazywanie przeciwieństwa cechy istotnej dla męskości hegemonicznej. Jest to zatem przede wszyst- 
kim prezentacja cech i zachowań określanych mianem „kobiecych”, czyli na przykład emocjonalność lub słabość fizyczna (Connell 1995). Elementy męskości podporządkowanych są zapożyczane w celu hybrydyzacji męskości dominujących. Elementy te inkorporowane przez męskości dominujące zmieniają znaczenie, jednak nosiciele tych cech przynależący do grupy męskości podporządkowanych nie mają takiej mocy redefinicji. Demetriou (2001) twierdzi, że męskości podporządkowane i marginalizowane nie mają wpływu na męskości hegemoniczne.

Co zatem z hybrydyzacją męskości grup mężczyzn, którzy nie należą do grup uprzywilejowanych? Czy można w ogóle mówić o hybrydach męskości podporządkowanej i czym się różnią? Męskości dominujące zapożyczające element męskości podporządkowanych włączają go, czynią akceptowalnym, ale też redefiniują. Dochodzi do zmiany znaczeń, które zapożyczone praktyki niosły wcześniej. Istotne jest zatem to, która grupa zapożycza, gdyż wówczas dany element ważny inaczej i w inny sposób redefiniowane jest inkorporowanie danego elementu. Można zastanowić się, czy owo zapożyczenie w przypadku męskości podporządkowanej zostanie uznane, czy podważone i czy dojdzie do rozpoznania próby przekroczenia granicy.

Badania dotyczące hybrydyzacji męskości w znacznym zakresie dotyczą grup młodych, identyfikujących się jako heteroseksualni, białych mężczyzn. Pokazuje to, że na modyfikacje mogą pozwolić sobie przede wszystkim grupy uprzywilejowane. Bridges i Pascoe (2014: 249) zaznaczają jednak, że nie tylko ta grupa realizuje męskości hybrydowe, również męskości marginalizowane i podporządkowane. Mężczyźni z grup dominujących włączając aspekty męskości podporządkowanych, nic na tym nie tracą, a wręcz zyskują. Dlatego tak istotne jest pytanie czy jest możliwe i co zmienia włączenie w męskości podporząakowane elementów czy praktyk męskości dominujących? Bridges i Pascoe (2014) nie podają przykładów hybrydyzacji męskości podporządkowanych. Wskazują tylko jako męskość hybrydową męskość inkluzywną, opisaną przez Erica Anderson (2009). Również na przykład męskości inkluzywnej powołuje się Karla Elliott (2020a; 2020b), która wskazuje, że męskość inkluzywna pokazuje jak dochodzi do przejścia, inkorporacji męskości z marginesu do centrum.

Bartek Lis (2015) prowadząc badania wśród gejów skupia się na grupie mężczyzn, który określić można mianem podporządkowanych. Bycie nieheteroseksualnym mężczyzną wyklucza bowiem z potencjalnej możliwości realizowania męskości hegemonicznej. Lis w swych badaniach ukazuje jak mężczyźni realizują wzorce socjalizacyjne i starają się zapożyczać praktyki (np. chodzenie z dziewczyną; nie mówienie o swojej homoseksualności), które pozwalałby ukryć ich homoseksualność, zamaskować. Badania te mogą być przykładem ukazania hybrydyzacji męskości podporządkowanych. Jednak celem tej hybrydyzacji nie jest włącznie elementów męskości podporządkowanych i dystansowanie się wobec męskości hegemonicznej. Wręcz przeciwnie. Dochodzi tu do prób włączenia elementów/praktyk męskości hegemonicznej i zbliżenia się do niej w wymiarze symbolicznym. Hybrydyzacja męskości w takim ujęciu różni się od opisanej przez Bridgesa i Pascoe (2014; 2018), przede wszystkim w kontekście opisanych konsekwencji. 


\section{ZAKOŃCZENIE}

Zmiany męskości są tematem, który poruszany jest niezwykle często w literaturze przedmiotu. Hybrydyzacja jest przykładem takiej zmiany. Jest ona uwikłana w zależności władzy na dwóch poziomach: zewnętrznym i wewnętrznym. To zatem nie tylko relacja nierówności genderowych, podporzadkowania w obrębie płci, ale również w obrębie męskości. Teoria R.W. Connell (1995) jest krytykowana, jednak jej wkład w rozwój refleksji w ramach KSMM jest bezapelacyjny i często stanowi punkt odniesienia dla dalszych badań. Tak dzieje się w przypadku męskości hybrydowych, które bazują na założeniach teorii R.W. Connell. Sposób kształtowania męskości hybrydowych został opisany teoretycznie przez Tristana Bridges'a i C.J. Pascoe (2014; 2018). Badacz i badaczka prezentują konsekwencje związane ze sposobem konstruowania męskości hybrydowych, pokazują, że są one związane ze zmianami przyczyniającymi się do podtrzymywania dominacji mężczyzn nad kobietami i dominacji pewnych grup mężczyzn nad innymi. Bridges i Pascoe $(2014 ; 2018)$ opisując męskości hybrydowe nie wartościują zmian, którym owe męskości podlegają. Opisują mechanizmy i konsekwencje zmian, jednak starają się przedstawić zmianę jako obiektywną. W moim przekonaniu nie ma w tej zmianie neutralności, nie jest to po prostu zmiana. Wyłonienie męskości hybrydowych postrzegam jako próbę utrzymania władzy, dzięki pozornym zmianom. Zmianom, które mają pozwolić utrzymać status quo. Rozważania na temat hybrydyzacji męskości wskazały i podkreśliły znaczenie mechanizmu patriarchalnej dywidendy i być może refleksja nad sposobem zmiany opisanym w hybrydyzacji męskości przyniesie owoce w postaci modyfikacji perspektywy badań. Bridges i Pascoe nie poświęcają uwagi męskościom hybrydowym, które wyłaniają się z męskości podporządkowanych. Wspominają o nich informując, że one również podlegają hybrydyzacji. Jest to obszar do dalszych rozważań teoretycznych i badań.

Męskości hybrydowe zyskują, przybierają złudną formę męskości prorównościowych lub „miękkich”, ale tak naprawdę wykorzystują praktyki męskości podporządkowanych, inkorporując je i redefiniując. Nic się nie zmienia, to tylko wilk w owczej skórze. Męskości dominujące modyfikują się, ulegają metamorfozie przez włączenie elementów męskości podporządkowanych, adoptują je, by nadal utrzymać autorytet i władzę. „Stara” męskość hegemoniczna już nie pasuje. Zmieniły się czasy i możliwość głoszenia pewnych twierdzeń, zachowań - ponieważ nie ma możliwości ich stosowania, trzeba wykorzystać inne. Można więc przyjąć modę, jako element wyglądu, czy czułość, wyrażaną w sposób oczekiwany społecznie. To sposoby na podtrzymanie władzy. 


\section{BIBLIOGRAFIA}

Anderson, Eric. 2009. Inclusive masculinity: the changing nature of masculinities. New York: Routledge.

Arcimowicz, Krysztof. 2020. Oblicza męskości w neoserialach. Hegemonia-kontaminacja-inkluzja. Białystok: Wydawnictwo UWB.

Arcimowicz, Krzysztof. 2022. „Męskość hybrydowa i władza. Krytyczna analiza dyskursu neoserialu Dom z papieru.” Miscellanea Antropologica et Sociologica, w druku.

Arxer, Steven L. 2011."Hybrid Masculine Power: Reconceptualizing the Relationship Between Homosociality and hegemonic Masculinity." Humanity \& Society 35: 390-422. DOI: https://doi.org/10.1177/016059761103500404

Barber, Kristen. 2008. “The Well-Coiffed Man: Class, Race and Heterosexual Masculinity in the Hair Salon." Gender and Society 22(4): 455-476. DOI: https://doi. org/10.1177/0891243208321168

Beasley, Christine. 2008a. “Reply to Messerschmidt and to Houston.” Men and Masculinities 11(1): 114-115.

Beasley, Christine. 2008b. "Rethinking hegemonic masculinity in a globalized world.” Men and Masculinities 11(1): 86-103.

Berggren, Kalle. 2014. "Sticky Masculinity: Post-structuralism, Phenomenology and Subjectivity in Critical Studies on Men.” Men and Masculinities 173(3): 231-252. DOI: https://doi.org/10.1177/1097184X14539510

Bhabha, Homi. 1998. “The Commitment to Theory.” New Formations 5: 5-23.

Bridges, Tristan. 2010. “Men just weren’t made to do this.” Gender \& Society 24(1): 5-30. DOI: https://doi.org/10.1177/0891243209356924

Bridges, Tristan i C. J. Pascoe. 2014. "Hybrid masculinities: New directions in the sociology of men and masculinities.” Sociology Compass 8(3): 246-258. DOI: https:// doi.org/10.1111/soc4.12134

Bridges, Tristan i C.J. Pascoe. 2018. “On Elasticity of Gender Hegemony. Why hybrid Masculinities Fail to Undermine Gender and Sexual Inequality”. Ss. 254-274 w Gender Reckonings: New Social Theory and Research, pod red. J.W. Messerschmidt, P.Y. Martin, M.A. Messner, R.W. Connell. New York: NYU Press.

Connell, Reawen W. 1995. Masculinities. Sydney: Allen \& Unwin.

Demetriou,DemetrakisZ.2001.“Connell'sconceptofhegemonicmasculinity:Acritique.” Theory \& Society 30(3): 337-361. DOI: https://doi.org/10.1023/A:1017596718715

Donaldson, Mike. 1993. "What is hegemonic masculinity." Theory \& Society 22(5): 643-657. DOI: https://doi.org/10.1007/BF00993540

Donovan, Brian. 1998. "Political consequences of private authority: Promise Keepers and the transformation of hegemonic masculinity.” Theory \& Society 27(6): 817843. DOI: https://doi.org/10.1023/A:1006909132442

Elliott, Karla. 2015. “Caring masculinities: Theorizing an emerging concept.” Men and Masculinities 12: 1-20. DOI: https://doi.org/10.1177/1097184X15576203

Elliott, Karla. 2020a. "Bringing in margin and centre: 'Open' and 'closed' as concepts for considering men and masculinities.” Gender, Place \& Culture 27(12): 17231744. DOI: https://doi.org/10.1080/0966369X.2020.1715348 
Elliott, Karla. 2020b. Young Men Navigating Contemporary Masculinities. Switzerland: Palgrave Macmillan.

Haverda, Timothy. 2019. Hybridizing masculinity: gender identity negotiation among men's rights activists. Pobrano 10 listopada 2020 (https://www.proquest.com/ openview/684f78c428f4de06616fb4dc75a19ea 7/1?pq-origsite=gscholar \&cbl $=18750 \&$ diss $=y)$.

Hearn, Jeff, 1996. "Is masculinity dead?: A critical account of the concept of masculinity/masculinities”. Ss. 202-217 w Understanding masculinities: Social relations and cultural arenas, pod red. M. Mac and Gaill. Milton Keynes: Open University Press.

Hearn, Jeff. 2004. "From hegemonic masculinity to the hegemony of men." Feminist Theory 5(1): 49-72. DOI: https://doi.org/10.1177/1464700104040813

Hearn, Jeff. 2009. “Deconstructing the hegemony of men and masculinities - presentation of the research theme”. Ss. 13-26 w J. Hearn, red. GEXcel Work Progress Report Volume 5. Pobrano 15 października 2020 (http://liu.diva-portal.org/smash/ get/diva2:792339/FULLTEXT01.pdf).

Howson, Richard. 2005. Challenging hegemonic masculinity. Londyn: Routledge.

Howson, Richard. 2008. "Hegemonic masculinity in the theory of hegemony." Men and Masculinities 11(1): 109-113. DOI: https://doi.org/10.1177/1097184X08315105

Kimmel, Michael. 1995. The Politics of Manhood: profeminist men respond to the mythopoetic men's movement (and the mythopoetic leaders answer). Philadelphia: Temple University Press.

Kimmel, Michael S. 2017. Angry White Men: American Masculinity at the End of an Era, 2nd ed. New York: Nation Books.

Kluczyńska, Urszula. 2017a. Mężczyźni w pielęgniarstwie. W stronę męskości opiekuńczej. Poznań: Wyd. UMP.

Kluczyńska, Urszula. 2017b. “Motives for choosing and resigning from nursing by men in Poland and the definition of masculinity: a qualitative study." Journal of Advanced Nursing 73(6): 1366-1376. https://doi.org/10.1111/jan.13240

Kluczyńska, Urszula. 2018. „Socjologiczne studia nad mężczyznami i męskościami w Polsce. Obszary, perspektywy, teorie.” Wielogłos 37(3): 1-20. DOI: 10.4467/2084395XWI.18.026.10190

Kluczyńska, Urszula. 2021. „Caring masculinity or hybrid masculinity? An analysis of research results on male nurses.” Society Register 5(1): 7-26. DOI: 10.14746/ sr.2021.5.1.01

Lis, Bartek. 2015. Gejowskie (nie)męskości. Normy płciowe a strategie tożsamościowe gejów. Gdańsk: Katedra.

Masters, N. Tatiana. 2010. “'My Strength is Not for Hurting': Men's Anti-Rape Websites and their Construction of Masculinity and Male Sexuality.” Sexualities 13(1): 33-46. DOI: https://doi.org/10.11.77/1363460709346115

Messner, Michael. 1993. “Changing men' and feminist Politics in the United States.” Theory \& Society” 22(5): 723-737.

Messner, Michael. 2007. “The Masculine of the Governator.” Gender and Society 21(4): 461-480. DOI: https://doi.org/10.1177/0891243207303166

Sarvan, David. 1998. Talking Like A Man: White Masculinity, Machismo, and Contempo- 
rary American Culture. Princeton, NJ: Princeton University Press.

Waling, Andrea. 2018. "Rethinking Masculinity Studies: Feminism, Masculinity, and Poststructural Accounts of Agency and Emotional Reflexivity." Journal of Men's Studies 27(1): 89-107. DOI: https://doi.org/10.1177/1060826518782980

Ward, Jane. 2015. Not gay. Sex between straight white men. Nowy Jork: NYU Press.

Wetherell, Margaret i Nigel Edley. 1999. "Negotationg hegemonic masculinity: Imaginary positions and psycho-discursive practices." Feminism \& Psychology 9(3): 335-356. DOI: https://doi.org/10.1177/0959353599009003012

Whitehead, Stephen. 1999. “Hegemonic masculinity revised.” Gender, Work and Organization 6(1): 58-62. DOI: https://doi.org/10.1111/1468-0432.00069

Whitehead, Stephen M. 2002. Men and Masculinities. Oxford: Polity Press.

Wojnicka, Katarzyna. 2021. "Men and masculinities in times of crisis: between care and protection.“ NORMA 16(1): 1-5. DOI: $10.1080 / 18902138.2021 .1885860$

\section{Hybrid masculinities or a wolf in sheep's clothing. Defining the concept}

ABSTRACT: Critical Studies on Men and Masculinities offer an array of terms and categories to describe masculinities and gender relations. The hegemonic masculinity theory of R.W. Connell is the most common theory that has monopolised studies on masculinities. However, it has been criticised heavily, the result being new ways of describing masculinities, including hybrid masculinities. The main aim of the article is to provide Polish readers with comprehensive descriptions and a critique of theoretical theories on men and masculinities with special focus on the hybrid masculinity theory. The analysis provides definitions of hybrid masculinities and considers consequences of hybridisation. Besides, the author analyses studies, which use the concept of hybrid masculinities. Finally, the hybrid masculinity theory is presented and discussed in the light of other theories of masculinities.

KEYWORDS: sociology of masculinities, hybrid masculinities, hegemonic masculinity, Critical Studies on Men and Masculinities, CSMM 
